\title{
Digitalisasi Desa dan Potensi Wisata Di Desa Kerta, Kabupaten Gianyar Menuju Pariwisata 4.0
}

\author{
Bagus Putu Wahyu Nirmala, Nengah Widya Utami, A.A Istri Ita Paramitha \\ Sekolah Tinggi Manajemen Informatika dan Komputer (STMIK) Primakara
}

\begin{abstract}
ABSTRAK
Desa Kerta adalah salah satu desa yang telah ditetapkan sebagai desa wisata oleh pemerintah Kabupaten Gianyar pada tahun 2018 bersama 8 desa lainnya. Terkait infrastruktur sebagai desa wisata sudah cukup siap seperti akses jalan, gapura Kebun Raya Gianyar, petunjuk arah daya tarik wisata, penataan Pucaksari Camping Ground, pembuatan jalur trekking, pembuatan jalur cycling, dan sebagainya. Meskipun baru setahun pembangunan ini tidak terlepas dari pasang surut. Saat pengusul melakukan observasi awal, masa jabatan Kepala Desa telah habis sehingga pembangunan desa wisata menjadi kurang terarah terutama terkait pemasaran. Program pemerintah terkait pemasaran desa wisata juga kurang oleh Pokdarwis. Permasalahan yang terjadi di desa mitra yakni sedikitnya pengetahuan dan kurangnya keterlibatan masyarakat dalam melakukan promosi potensi wisata dan tidak adanya fasilitas penunjang untuk memasarkan paket-paket wisata yang dikelola oleh kelompok sadar wisata di Desa Kerta. Dari permasalahan tersebut maka dalam kegiatan pengabdian masyarakat ini akan mempertimbangkan 2 aspek yang akan dikerjakan diantaranya adalah aspek teknologi informasi dengan membuat website desa, website BUMDes, website penjualan paket wisata, dan pembuatan aplikasi Augmented Reality. Dalam upaya meningkatkan promosi dan pemasaran paket wisata maka akan dilakukan sosialisasi pemanfaatan website dan aplikasi yang telah dikembangkan, pelatihan pengelolaan website dan aplikasi, serta pelatihan optimasi teknologi SEO (Search Engine Optimation) dan Google My Business kepada kelompok pengelola paket wisata. Setalah pembuatan website dan aplikasi, selanjutnya dilakukan kegiatan sosialisasi bersama masyarakat mitra. Kegiatan ini dilakukan dengan memberikan informasi kepada masyarakat mitra tentang pemanfaatan website dan aplikasi yang telah dikembangkan untuk mendukung perkembangan potensi wisata dan peningkatan keterlibatan masyarakat di dalam pengelolaan desa wisata di Desa Kerta. Kegiatan pelatihan ini khusus ditujukan kepada kelompok pengelola desa wisata di Desa Kerta. Kelompok pengelola desa wisata ini bertugas sebagai administrator dengan melakukan manajemen seluruh konten pada website dan aplikasi. Pelatihan ini juga ditujukan kepada kelompok pengelola desa wisata sebagai upaya peningkatan promosi desa dan objek wisata melalui pemanfaatan teknologi SEO dan Google My Bussiness pada website yang telah dikembangkan. Target capaian dalam kegiatan program kemitraan masyarakat ini adalah peningkatan keterampilan mitra hingga $80 \%$, peningkatan pengetahuan mitra hingga $90 \%$.
\end{abstract}

Kata kunci : Desa, Kerta, Wisata, Website, Aplikasi

\section{PENDAHULUAN}

Pulau Bali sebagai barometer pariwisata Indonesia menjadi tolak ukur bagi pengembangan pariwisata destinasi lainnya. Pembangunan pariwisata Bali yang telah dimulai sejak 40 tahun lalu mampu menjadikan sektor ini sebagai sektor andalan Pulau Bali selama bertahun-tahun. Industri pariwisata telah menciptakan multiplier effect bagi Bali. Setidaknya pariwisata memberikan dampak penerimaan devisa, peningkatan perekonomian masyarakat, penciptaan kesempatan / lowongan kerja dan dampak pembangunan infrastruktur pada umumnya. Di sisi yang lain, pembangunan pariwisata di Bali telah diarahkan pada pariwisata budaya dimana pembangunannya haruslah tetap menjaga kelestarian budaya Bali. Oleh karenanya, konsep pembangunan pariwisata Bali terus dikembangkan hingga saat ini agar multiplier effect yang ditimbulkan mampu menjaga dan melestarikan budaya Bali, bukan sebaliknya.

Salah satu konsep yang dikembangkan dan sedang digencarkan oleh pemerintah daerah adalah desa wisata. Konsep desa wisata diharapkan memberikan variasi daya tarik wisata agar tidak terjebak dalam corak pariwisata masal (mass tourism) karena desa yang merupakan tempat sebagian besar daya tarik wisata berada tentu memiliki kearifan lokal yang potensial diangkat dan tentu berbeda dengan desa lainnya. Melalui desa wisata akan tercipta pariwisata yang mampu menyerap tenaga kerja pedesaan (pro job), menumbuhkan perekonomian desa (pro growth) dan sebagai alat menekan angka kemiskinan (pro poor). 


\section{METODE PELAKSANAAN}

\subsection{Metode Penerapan Kegiatan}

Metode pelaksanan kegiatan pengabdian kepada masyarakat ini mengikuti alur pelaksanaan kegiatan seperti pada Gambar 1.

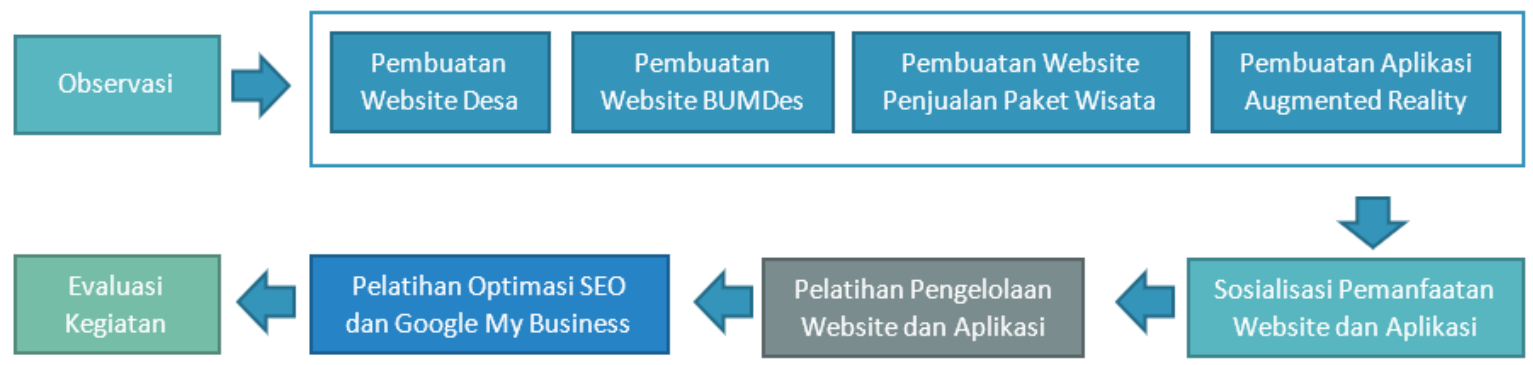

Gambar 1. Alur Pelaksanaan Kegiatan

Adapun penjelasan dari setiap kegiatan pada gambar diatas yaitu sebagai berikut.

1. Observasi, dilakukan oleh Ketua Pengusul

Tahap pertama yang dilakukan dalam pelaksanaan PKM ini yaitu melakukan observasi ke lokasi mitra. Hal ini bertujuan untuk mengetahui kondisi desa dan melakukan analisis serta memberikan solusi terhadap permasalahan yang sedang dihadapi di Desa Kerta.

2. Pembuatan Website dan Aplikasi, dilakukan oleh Anggota Pengusul

Berdasarkan analisis situasi dan permasalahan mitra, maka kegiatan PKM ini memberikan solusi pada aspek [1] Teknologi Informasi, [2] Promosi dan Pemasaran Paket Wisata. Pada tahap ini dilakukan pembuatan website Desa, Website BUMDes, Website Penjualan Paket Wisata, dan Aplikasi Augmented Reality dalam rangka digitalisasi desa dan daya tarik wisata yang ada di Desa Kerta.

3. Sosialisasi, dilakukan oleh Ketua dan Anggota Pengusul

Setelah pembuatan website dan aplikasi, selanjutnya dilakukan kegiatan sosialisasi bersama mitra. Kegiatan ini dilakukan dengan memberikan informasi kepada mitra tentang pemanfaatan website dan aplikasi yang telah dikembangkan untuk mendukung perkembangan potensi wisata dan peningkatan keterlibatan masyarakat di dalam pengelolaan desa wisata di Desa Kerta. Dokumentasi kegiatan ini berupa foto kegiatan sosialisasi dan video kegiatan.

4. Pelatihan Pengelolaan Website dan Aplikasi, dilakukan oleh Anggota Pengusul Kegiatan pelatihan ini khusus ditujukan kepada kelompok pengelola desa wisata (Pokdarwis) di Desa Kerta. Pokdarwis ini bertugas sebagai administrator dengan melakukan manajemen seluruh konten pada website dan aplikasi.

5. Pelatihan Optimasi SEO dan Google My Business, dilakukan oleh Ketua Pengusul

Pelatihan ini juga ditujukan kepada Pokdarwis sebagai upaya peningkatan promosi desa dan objek wisata melalui pemanfaatan teknologi SEO dan Google My Bussiness pada website yang telah dikembangkan.

6. Evaluasi Kegiatan

Pada tahap terakhir dilakukan evaluasi kegiatan yang bertujuan untuk memantau perkembangan desa setelah dilakukannya kegiatan pengabdian kepada mitra. Hal ini dilakukan dengan cara mendokumentasikan kegiatan dan pembuatan laporan.

\subsection{Peserta Pengabdian}

Dalam melaksanakan kegiatan PKM mitra turut berperan aktif diantaranya yaitu:

1. Keterlibatan Aparatur Desa di setiap kegiatan PKM. 
2. Keterlibatan Kelompok Sadar Wisata

3. Keterlibatan Karang Taruna

4. Keterlibatan Pelaku UMKM

Semua komponen yang dimiliki mitra terlibat dalam kegiatan pengabdian ini dari persiapan data untuk website dan apps. Kemudian mengarahkan potensi-potensi wisata saat di tim pelaksana melaksanakan survei potensi. Selain itu, Kepala Desa Mitra juga sangat mendukung semua kegiatan yang dilaksanakan di lapangan dengan menyediakan sarana dan prasana mulai dari sosialisasi hingga dilakukan pelatihan.

\section{HASIL DAN PEMBAHASAN}

\subsection{Hasil Kegiatan}

Melalui kegiatan PKM ini informasi tentang Desa Kerta dapat diakses secara global melalui website oleh calon wisatawan sehingga meningkatkan minat kunjungan langsung. Berikut adalah tampilan website yang telah dikembangkan.

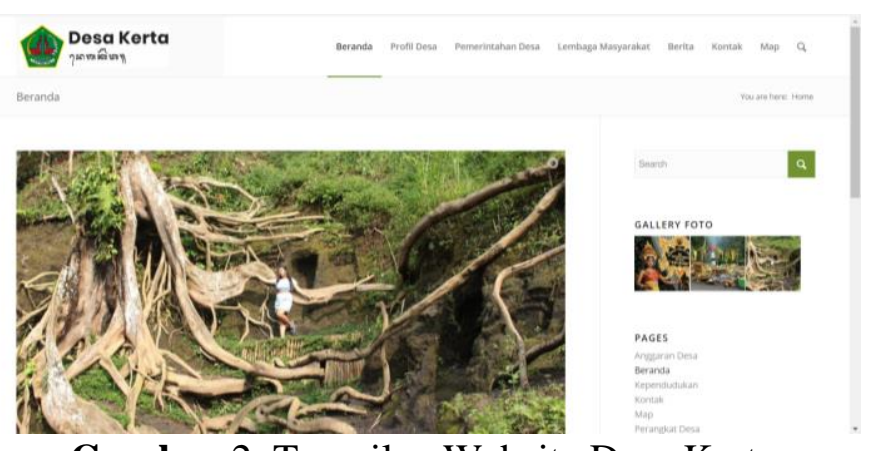

Gambar 2. Tampilan Website Desa Kerta

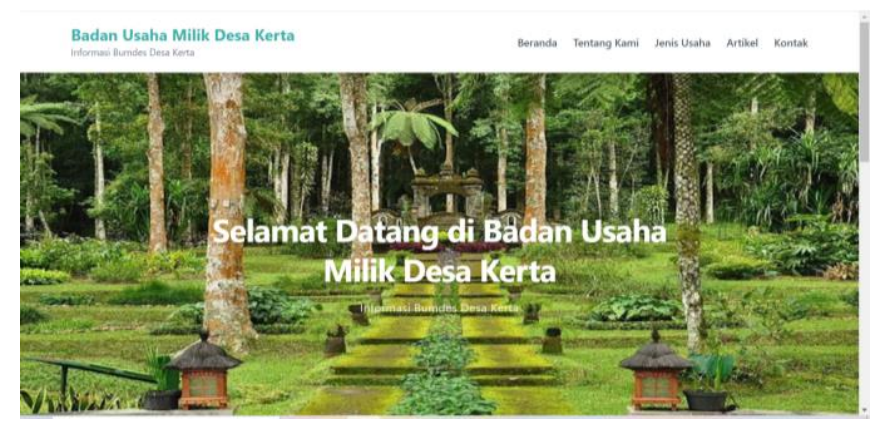

Gambar 3. Tampilan Website Bumdes Desa Kerta

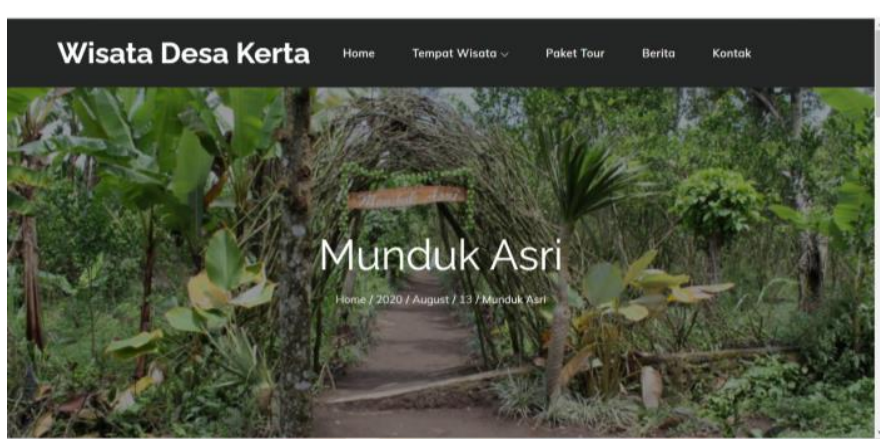

Gambar 4. Tampilan Website Wisata Desa Kerta

Ketika wisatawan sudah mengunjungi Desa Kerta, wisatawan dapat menggunakan aplikasi Augmented Reality Desa Kerta. Aplikasi AR Desa Kerta merupakan aplikasi guiding real time yang dapat digunakan oleh wisatawan selama ekplorasi objek wisata. Dengan adanya 
aplikasi ini akan menimbulkan potensi pekerjaan sebagai tour guide lokal karena saat wisatawan menggunakan aplikasi ini, pengelola potensi wisata seperti Pokdarwis Desa Kerta akan menerima notifikasi kemudian Pokdarwis dapat menghampiri wisatawan tersebut untuk memandunya selama eksplorasi potensi wisata.

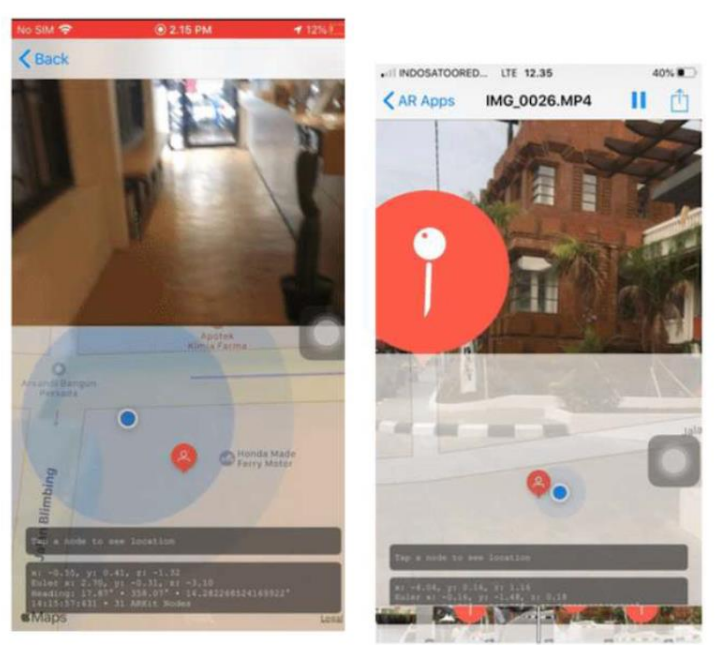

Gambar 5. Tampilan AR Desa Kerta

Dari sekian banyak potensi wisata beberapa sudah dipromosikan dan bahkan paket wisatanya sudah dipasarkan di aplikasi AR Desa Kerta sehingga siap untuk dipesan oleh wisatawan. Tabel berikut menunjukkan jumlah potensi wista dan paket wisata sebelum dan saat pengabdian berjalan.

Tabel 1. Perbandingan Keadaan Mitra Sebelum dan Saat Pengabdian Berjalan

\begin{tabular}{|l|l|l|}
\hline Keadaan & $\begin{array}{l}\text { Sebelum } \\
\text { Pengabdian }\end{array}$ & Saat Pengabdian Berjalan \\
\hline $\begin{array}{l}\text { Potensi Wisata Dipromosikan di } \\
\text { Aplikasi Mobile AR }\end{array}$ & 0 potensi wisata & 11 potensi wisata \\
\hline $\begin{array}{l}\text { Paket Trip Wisata Dipasarkan di } \\
\text { Aplikasi Mobile AR }\end{array}$ & 0 paket wisata & $\begin{array}{l}\text { 3 paket (village tour, } \\
\text { cycling, dan camping) }\end{array}$ \\
\hline
\end{tabular}

Dalam kegiatan PKM ini pengetahuan mitra di bidang teknologi informasi juga ditingkatkan melalui kegiatan pelatihan pengelolaan website oleh perangkat desa, pelatihan penggunaan aplikasi Augmented Reality oleh Kelompok Sadar Wisata (POKDARWIS), pelatihan SEO dan Google My Business bagi masyarakat yang memiliki UMKM.

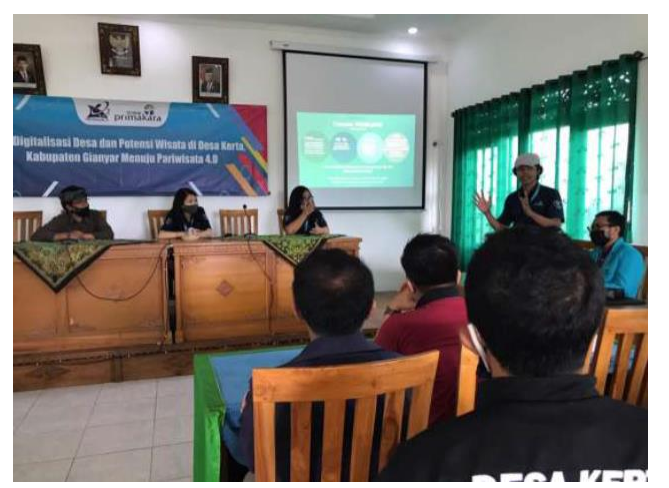

Gambar 6. Sosialisasi Website Desa Kerta 


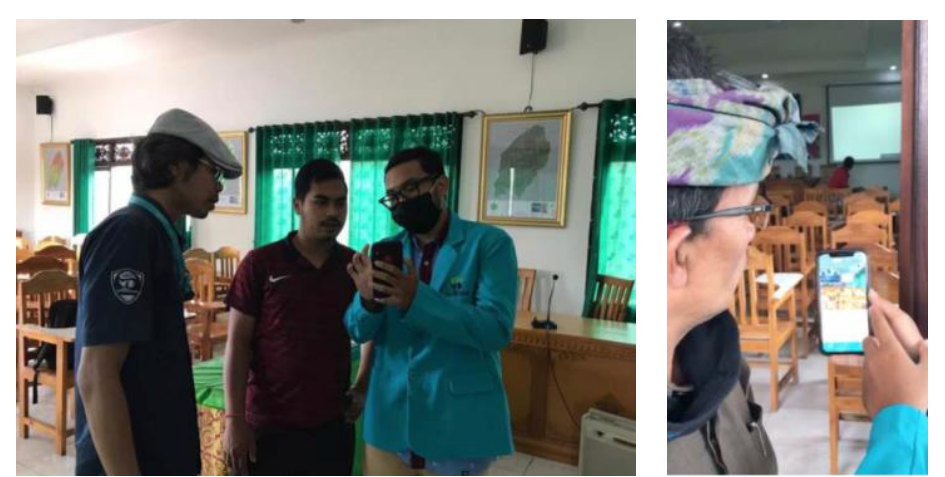

Gambar 7. Pelatihan Penggunaan Aplikasi AR Desa Kerta

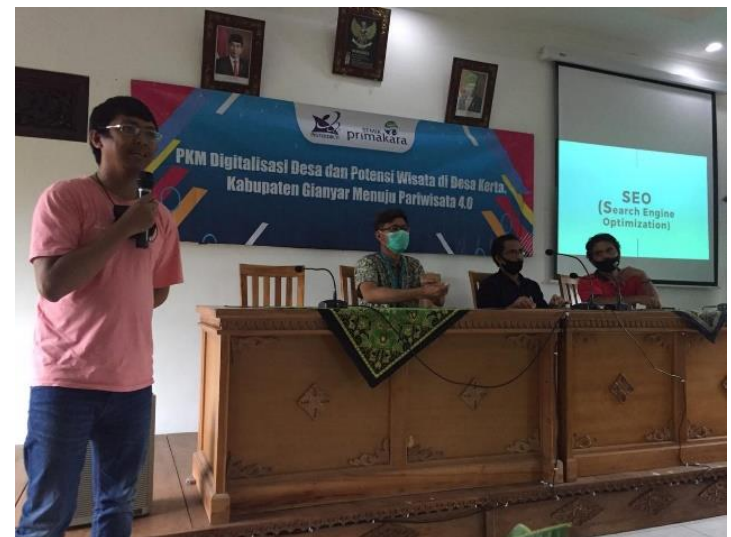

Gambar 8. Pelatihan SEO dan Google My Bussiness

Dampak Sosial yang diberikan melalui kegiatan PKM ini adalah cerita rakyat / legenda / local value dapat tersampaikan secara digital dan informasi di validasi langsung local expert. Wisatawan memiliki akses informasi terhadap aturan-aturan adat yang berlaku ketika ingin melakukan eksplorasi terhadap potensi wisata yang ada di Desa Kerta. Dengan demikian potensi wisata yang ada di Desa Kerta dapat terjaga kelestariannya dan wisatawan secara bijak berwisata di Desa Kerta.

\subsection{Penyelesaian Masalah}

Seluruh rangkaian kegiatan yang dilaksanakan mulai dari observasi, pembuatan Website dan Aplikasi, sosialisasi, pelatihan pengelolaan Website dan Aplikasi, pelatihan Optimasi SEO dan Google My Business, serta evaluasi kegiatan yang dilaksanakan oleh tim pelaksana dapat terlaksana dengan baik. Dapat disimpulkan bahwa tingkat efektivitas pelatihan berkisar $80 \%$. Konteks tingkat efektivitas didasarkan atas keberhasilan pelatihan yang telah menyelesaikan tes pada yang diberikan.

\section{KESIMPULAN DAN SARAN}

Pada Pelaksanaan Program Kemitraan Masyarakat (PKM) dengan judul Digitalisasi Desa dan Potensi Wisata dalam rangka menuju Pariwisata 4.0 telah terlaksana di Desa Kerta, Gianyar. Pelaksanaan PKM ini meliputi pengembangan website Profil Desa, website Potensi Wisata, website BUMDes, dan aplikasi Augmented Reality Desa Kerta, sosialisasi, dan pendampingan pemanfaatan website dan aplikasi. Permasalahan yang ditemui saat implementasi di lapangan seperti terbatasnya pertemuan dan koordinasi serta sedikitnya data pendukung sudah diberikan alternatif solusi untuk memperlancar kegiatan. Selanjutnya, implementasi website dan aplikasi harus dilakukan secara bertahap. Untuk itu, perlu dilakukan pendampingan secara intensif. 


\section{UCAPAN TERIMAKASIH}

Penulis mengucapkan terima kasih kepada RISTEK-BRIN atas dukungan sepenuhnya dalam pendanaan kegiatan Pengabdian Kepada Masyarakat ini.

\section{DAFTAR PUSTAKA}

Nirmala, B.P.W., Lavianto, S. (2019). Pemanfaatan Digital Enabler Dalam Transformasi Pemasaran Desa Wisata Berbasis Kerakyatan di Bali. Jurnal Teknologi Informasi dan Komputer, 5(1).

Dantes, G. D., Sudarma, K., \& Suputra, H. (2016). Virtual Reality Dan Augmented Reality: Pemberdayaan Wisata Bawah Laut Dalam Rangka Meningkatkan Daya Dukung Pariwisata. Seminar Nasional Teknologi Vokasi dan Teknologi, Hal. 457-464.

Purba, F.R. (2016). Pemanfaatan Sistem Informasi Geografi Dan Augmented Reality Untuk Pembuatan Peta Pariwisata Daerah Istimewa Yogyakarta. Universitas Gadjah Mada. Yogyakarta. 